\title{
NUDA, CZYLI DEKONSTRUKCJA PODMIOTU. SARTRE - CIORAN - PESSOA
}

Patryk Szaj

Uniwersytet im. Adama Mickiewicza w Poznaniu

\section{/// Paradygmat nudy?}

Chciałbym w niniejszym artykule potraktować nudę jako jeden $\mathrm{z}$ istotowych wyznaczników epoki, prądu lub nurtu kultury europejskiej, które zwykło się ujmować pod zbiorczą nazwą modernizmu. Będę przy tym korzystał z rozpoznań kilkorga badaczy, z różnych powodów uznających modernizm za przełomowe zjawisko dla świata Zachodu. Jednym z nich jest angielski socjolog i geograf kulturowy, Ben Anderson, twierdzący, że poczucie wyobcowania i bezładu podmiotu nieuchronnie wiąże się z nuda jako doświadczeniem specyficznie nowoczesnym, niewystępującym we wcześniejszych epokach (2004: 739-754). Tezie tej wtóruje Patricia Meyer Spacks, która wręcz nazywa modernizm „paradygmatem nudy” (1995: 27, cyt. za: Toohey 2012: 29-30). Przede wszystkim jednak gruntowne studium na temat nudy jako „doświadczenia bez właściwości” przedstawiła Elizabeth Goodstein (2005). Istnieją także autorzy - tacy jak Richard Sheppard (2004) - implicytnie uznający nudę za jeden z wyznaczników modernizmu, choć nie stanowi ona głównego obiektu ich zainteresowań. Na gruncie polskim zaś „nieokreśloność nudy” badali np. Wojciech Bałus (1996) czy Michał Paweł Markowski (1999), który przy okazji zaprezentował drobiazgową analizę narodzin nudy z ducha francuskiego oświecenia. Do każdego z wymienionych badaczy będę się odwoływał w niniejszym szkicu, próbując obronić tezę, że nuda stanowi swoistą dekonstrukcję podmiotu nowoczesnego, wskazującą na fiasko wielkiego projektu, który mógłby nosić nazwę „tożsamości kartezjańskiej”, i skłaniającą do wypracowania nowych koncepcji podmiotowości. Za przykład takiego działania 
nudy posłuży mi twórczość trzech autorów modernistycznych: Jeana-Paula Sartre’a, Emila Ciorana i Fernanda Pessoi.

Nudę należy tu wszakże rozumieć w specyficzny sposób - przyjmuje ona znaczenie nie potoczne (znużenie, brak rozrywki), ale egzystencjalne, które określić można w punkcie wyjścia jako „bezbrzeżne, wszechogarniające poczucie pustki, izolacji i wstrętu w połączeniu z całkowitym brakiem zainteresowania [światem]" (Toohey 2012: 129). Z jednej strony wiąże się ona $z$ takimi - ponadczasowymi lub historycznymi - wariantami tego stanu jak melancholia, depresja, rozpacz czy acedia, z drugiej jednak - jako doświadczenie egzystencjalne pojawia się dopiero w nowoczesności i jest z nią nierozwiązywalnie spleciona, na co wskazuje choćby historia pojęcia „nuda” w językach zachodnich: jak podkreśla np. Elizabeth Goodstein, słowo boredom pojawiło się $\mathrm{w}$ języku angielskim dopiero w drugiej połowie XIX wieku (Oxford English Dictionary jego pierwsze użycie datuje na 1864 rok), pojawiło się - ściśle rzecz ujmując - znikąd, a jego etymologia pozostaje niejasna ${ }^{1}$. Goodstein twierdzi jednak, że jest ono ekwiwalentem francuskiego ennui, które występowało wprawdzie już w pierwszej połowie XII wieku w pieśniach trubadurów, ale początkowo wyrażało głęboki smutek, duchowy ból, osobliwie powiązany z utratą kochanki. Dopiero dla oświeceniowych encyklopedystów zaczęło oznaczać po prostu „,niedostatek wszelkiej przyjemności” (Goodstein 2005: 109²), który następnie - w XVIII i XIX wieku - przeszedł proces radykalnej demokratyzacji, stając się doświadczeniem coraz powszechniejszym. Z analogiczną zmianą znaczeniową mamy do czynienia w niemieckim słowie Langeweile, pierwotnie związanym z temporalnym rozumieniem nudy jako dłużenia się czasu, wypieranym jednak od początku XIX wieku przez rozumienie egzystencjalne: jako cierpienia stawiającego pod znakiem zapytania znaczenie i sens życia ludzkiego (zob. Goodstein 2005: 107-112).

Tak pojęta nuda może stanowić jeden z ważniejszych wyznaczników modernizmu, który - jako projekt, nurt, zespół prądów, epoka bądź moment przełomowy kultury europejskiej - od dawna rodzi rozliczne problemy metodologiczne. Jednym z niewielu pewnych sądów, które można o nim wypowiedzieć, jest fakt, że na Zachodzie przyjmuje on inne zna-

\footnotetext{
${ }^{1}$ Warto wszakże podkreślić, co czyni Goodstein, że określenia „to bore” - nudzić się, oraz „bore”nudziarz, pojawiły się w języku angielskim ok. pół wieku wcześniej (2005: 107). Być może wskazuje to na zwykłe egzystencjalne pierwszeństwo doświadczenia nudy jako procesu, który następnie zastyga w statycznej językowej wykładni jako określony, nazwany, zdefiniowany stan. Ponieważ jednak nuda jest przede wszystkim dynamicznym doświadczeniem, wciąż wymyka się jednoznacznym definicjom. Jest więc raczej procesem niż stanem, a przeto nie poddaje się językowej reprezentacji. ${ }^{2}$ Ten i każdy następny cytat z książki Elizabeth Goodstein podaję według własnego tłumaczenia.
} 
czenie niż w polskiej tradycji badawczej, gdzie zazwyczaj utożsamia się go z okresem Młodej Polski, mimo prób zmiany tego podejścia (zob. np. Nycz 1997, Markowski 2007). Jakie to jednak ma znaczenie? Odpowiedź na to pytanie nastręcza już niemałego kłopotu. Z grubsza wiadomo, jak nakreślić ramy chronologiczne modernizmu: w ujęciu najwęższym podaje się lata 1885-1935, w najszerszym - 1870-1950. Poza tym wszakże pojęcie to pozostaje bardzo nieokreślone.

Wydaje się, że owa nieokreśloność nie wynika bynajmniej z niedoskonałości narzędzi, jakimi badamy ten okres, ale z samej jego natury. W literaturze przedmiotu powszechnie wiąże się bowiem modernizm europejski z doświadczeniem wielkiego kryzysu kultury zachodniej oraz z - formułowanym na bieżąco - zespołem (heterogenicznych) odpowiedzi na ów kryzys. Do jego cech kluczowych zalicza się poczucie braku norm (anomia), zaabsorbowanie nihilizmem, nieciagłość, refleksyjność, alienację i osamotnienie, ciągle obecną groźbę chaosu, świadomość pęknięcia między jaźnią ${ }^{3}$ a światem (Sheppard 2004: 73). W takim ujęciu modernizm okazuje się nie tyle prądem, nurtem czy nawet epoka, ile momentem przełomowym lub wręcz punktem przesilenia kultury zachodniej. Richard Sheppard, znany badacz problematyki modernizmu europejskiego, postawił tezę, że dokonała się wówczas zmiana całego paradygmatu ${ }^{4}$ kulturowego: w rzeczywistość - dotychczas postrzeganą jako stabilna, harmonijna i rządząca się zasada przyczynowości - za sprawą odkryć naukowych (szczególnie fizycznych) wtargnął olbrzymi metaświat niepoznawalnej, nieporządkowalnej, chaotycznej, dalekiej od linearności i ciagłości energii, który rozbił ustalone struktury poznawcze człowieka, wyrażane przez klasyczną fizykę newtonowską. Podobnie zmieniło się pojmowanie „natury” ludzkiej. Podmiot - dotąd ujmowany na sposób kartezjański, jako racjonalne, punktowe, samoświadome cogito - okazał się wiązką nieciągłych struktur pozbawionych substancji i faktycznej jedności, drążonych przez to, co pod-świadome i ir-racjonalne (zob. Sheppard 2004: 92-111). Przenikliwe pisma Friedricha

\footnotetext{
${ }^{3}$ Jaźń w tym ujęciu można zdefiniować jako centrum, strukturę integrująca psychikę ludzką. W ogólniejszym znaczeniu stanowi ona jeden z dogmatycznych wyznaczników tożsamości kartezjańskiej: punktowej, samoświadomej, nierozciagłej, stojącej naprzeciw świata, wobec którego przyjmuje przede wszystkim postawę poznawczą (epistemologiczna). Jednym z następstw rozpadu tak pojętej jaźni jest podawanie w wątpliwość tożsamości substancjalnej na rzecz - rozmaicie pojętych - koncepcji tożsamości relacyjnej (zob. np. Sendyka 2015).

${ }_{4}^{4}$ Paradygmat przyjmuje tu znaczenie Kuhnowskie, zgodnie z którym jest on zbiorem pojęć i teorii tworzących podstawy danej nauki, będących kryterium uznania jakiejś działalności za naukowa. Tak ujęty paradygmat nie jest bynajmniej tożsamy z dogmatem, z czymś niepodważalnym i absolutnie pewnym. Przeciwnie - stanowi raczej pewien koncepcyjny światopogląd, raz na jakiś czas ulegający rewolucyjnemu przekształceniu (zob. Kuhn 1968).
} 
Nietzschego, Sigmunda Freuda czy Ernsta Macha poskutkowały - wyrażoną przez ostatniego z nich - tezą: „Ja” jest nie do uratowania (Mach 2009). Ja/jaźń/ego - jako hipostazowane zworniki sensu jednostki ludzkiej - zostały więc podane w wattpliwość. I właśnie ta druga zmiana stanowi, poniekąd, temat niniejszego artykułu.

\section{/// Sartre, Cioran, Pessoa - fenomenologia nudy}

Fenomen nudy egzystencjalnej doczekał się w modernizmie wielu różnorodnych, rozległych ujęć. Pisali o nim najsłynniejsi autorzy - od Charles’a Baudelaire’a, przez Franza Kafkę, Rainera Marię Rilkego, Virginię Woolf, Paula Valéry'ego (który - tak jak Goodstein - pisał, że nuda nie posiada oblicza - Valéry 1960: 582), aż po Samuela Becketta. Chciałbym prześledzić występowanie tego fenomenu w twórczości trzech pisarzy modernistycznych: Jeana-Paula Sartre’a, Emila Ciorana i Fernanda Pessoi. Wydaja się oni stanowić wdzięczne przykłady omawianego zagadnienia, gdyż ich pozycja w dyskursie humanistycznym jest dość osobliwa. Sartre’a - rzecz jasna - przede wszystkim utożsamia się z egzystencjalizmem, przez kilka lat będącym swoistą moda intelektualną Zachodu, następnie pokrywającym się coraz grubszą warstwą patyny lub też wchłanianym przez inne nurty refleksji, dla których stanowił tylko poboczny kontekst. W przeciwieństwie do autora Bytu i nicości, Cioran i Pessoa, pisarze (myśliciele?) niewątpliwie również egzystencjalni (lecz nie: egzystencjalistyczni!), przez wiele lat czekali na odkrycie i dopiero od niedawna cieszą się wzmożonym zainteresowaniem czytelniczym. Choć krąży nad nimi widmo egzystencjalizmu (Ciorana nazywano nieraz „epigonem Sartre'a” - Prokopski 2007: 268), to jednak wszelkie tego typu utożsamienia wydają się opierać na raczej powierzchownych analogiach, które - po głębszym namyśle szybko się rozsypują. W istocie, o wiele większe pokrewieństwo odnaleźć można między Cioranem i Pessoą niż pomiędzy nimi a Sartre'em. Cioran - radykalny krytyk egzystencjalistycznego „optymizmu”, heroizmu, zaangażowania w działanie - mówił: „Czuję się kimś na antypodach Sartre’a, wszystkich jego metod, a nawet postępowania w życiu” (1999: 47). Bardzo cenił natomiast wiersze Pessoi, niejednokrotnie utożsamiając się z ich podmiotem (2004: 726).

Wydaje się jednak, że tym, co wspólne dla Sartre’a, Ciorana i Pessoi, było właśnie doświadczenie nudy egzystencjalnej, choć i tu podkreślić trzeba istotna różnicę: podczas gdy Sartre uczyni nudę jedynie negatywnym przeżyciem, które należy przezwyciężyć w drodze ku egzystencji au- 
tentycznej, imperatywem Ciorana i Pessoi pozostało wytrwanie w nudzie, przesączanie jej przez siebie i destylowanie z niej odtrutek na absurd egzystencji. Spróbujmy więc - na początek - nakreślić swoistą „fenomenologię nudy" w ujęciu każdego z tych autorów. Na wstępie zauważyć trzeba, że wszyscy oni utożsamiali nudę z doświadczeniem przebiegającym na styku fizjologii i woli. Jej somatyczna strona objawiać się miała jako mdłości, niestrawności lub też - właśnie - nudności. Najwcześniej słowo „mdłości” pojawiło się u Sartre’a, który w 1938 r. wydał książkę pod takim właśnie tytułem, ale także u Ciorana i Pessoi odnajdziemy analogiczne fragmenty:

Jak zdefiniować nudę? To mieszanina niestrawności z katastrofą kosmiczna (Cioran 2004: 786).

Rzyganie nigdy nie jest czynnościa czysto fizyczną. Ileż nieurzeczywistnionych rzygań nosiłem w sobie w ciągu życia! Ze wszech miar: ssak męczony nudnościami (Cioran 2004: 338).

Życie można odczuwać jako mdłości w żołądku, istnienie własnej duszy jako dolegliwość mięśni (Pessoa 2007: 99).

Jak często boli mnie istnienie, wywołując mdłości do tego stopnia nieokreślone, że nie potrafię stwierdzić, czy są znudzeniem, czy zapowiedzią wymiotów (Pessoa, cyt. za: Markowski 2009: 287$\left.288^{5}\right)$.

Bohaterem debiutanckiej powieści Sartre’a jest Antoine Roquentin, typowy drobnomieszczanin, który nagle zaczyna odczuwać nadmierna świadomość istnienia. Tym właśnie są Mdłości: „Ja istnieję - świat istnieje. I ja wiem, że świat istnieje”, „nie jest to choroba ani przelotny napad: to jestem ja" (Sartre 1974: 174-175, 179). Nagłe wkroczenie Mdłości - owej „somatycznej idiosynkrazji” (Chwin 2010: 238) - w życie Roquentina cał-

\footnotetext{
${ }^{5}$ Niestety, nie udało mi się odnaleźć tego cytatu w polskim wydaniu Ksiegi niepokoju. Być może ma to związek z osobliwym statusem owej książki, która jest „dziełem w toku” - work in progress nigdy nieukończonym, nieposiadającym kanonicznej wersji, złożonym dopiero po śmierci Pessoi z tysięcy pozostawionych przez niego fragmentów, którymi redaktorzy wydań Księgi... w różnych językach operują mniej lub bardziej swobodnie (na ten temat zob. Zenith 2013). Tak na niemożność ukończenia swego opus magnum narzekał sam Pessoa: „Mój stan umysłu zmusza mnie, wbrew mojej woli, do ciężkiej pracy nad Ksiegq niepokoju. Ale to wszystko fragmenty, fragmenty, fragmenty" (cyt. za: Markowski 2009: 262). To ubolewanie również wydaje się emblematyczne: fragmentaryzacja wypowiedzi, niemożność ukończenia dzieła, bunt przeciw całości wydają się właśnie następstwami nudy egzystencjalnej jako dekonstrukcji podmiotu.
} 
kowicie wyobcowuje go ze świata, destruuje wszystkie dogmaty humanizmu, wewnątrz których toczyło się dotąd życie bohatera powieści, czyni z niego outsidera (Wilson 1959: 9-21), a także nieprzejednanego krytyka ustalonego porządku kultury i hierarchii społecznych. Krytyka ta nie odbywa się w imię ustanowienia jakiegoś nowego, lepszego, prawdziwszego lub sprawiedliwszego porządku, lecz w imię demaskacji czystego bezsensu życia - Roquentin odczuwa świat i istnienie jako absurdalne, pozbawione wartości:

Mdłości to sama egzystencja, przypadkowa, zbyteczna, bez racji bytu i usprawiedliwienia, absurdalna, bo nie dająca się sprowadzić do niczego. [...] To korzeń kasztanowca, ławka, trawnik, ogrodzenie, wszystkie przedmioty zawierają w sobie absurdalność. Absurdalny - to nie sprowadzalny do niczego innego, nie ukrywający za sobą żadnej racji istnienia, a więc przez nic nie wyjaśnialny. [...] [Ale też] Mdłości to jestem ja sam - „wiotki, osłabiony, sprośny, trawiący, chwiejący się od ponurych myśli - ja także byłem zbyteczny" (Puszko 1988: 47).

Nieokreślona absurdalność drąży Roquentina, nie potrafi on uzasadnić i usprawiedliwić swego istnienia, nie znajduje racji jakiegokolwiek bytu, nuda całkowicie opróżnia go z sensu. Absurd staje się dla niego absolutem:

I nie formułując niczego wyraźnie zrozumiałem, że odnalazłem klucz Istnienia, klucz do moich Mdłości, do mego własnego życia. [...] wszystko, co mogłem później uchwycić, sprowadza się do tej podstawowej absurdalności. [...] Chciałbym jednak określić tutaj absolutny charakter tej absurdalności. [...] doświadczyłem przed chwila absolutu: absolutu lub absurdu. [...] świat wyjaśnień i racji nie jest światem istnienia (Sartre 1974: 182-183).

Nuda okazuje się więc dla Roquentina-Sartre’a („Byłem Roquentinem, ukazałem w nim bez ogródek kanwę swojego życia" - napisze Sartre w autobiografii Stowa - 1968: 201) podszewka istnienia, czymś nieprzekraczalnym i niepodważalnym, przekraczającym i podważającym dogmaty racjonalizmu. Nibil est ratione - chciałoby się odwrócić twierdzenie Gottfrieda Leibniza. Samo istnienie jawi się przez to jako kosmiczny acte gratuit (zob. Franczak 2002: 46): „wszystko, co jest istnieniem, rodzi się bez powodu, przedłuża się przez słabość i umiera przypadkowo” (Sartre 1974: 
188). O ile jednak dla Sartre’a nuda stanowiła jedynie negatywny punkt wyjścia dla pozytywnych poszukiwań filozoficznych egzystencjalizmu („Egzystencjalizm jest humanizmem” - powie już w 1945 roku, jednym gestem przekreślając swoją wcześniejszą krytykę humanizmu - Sartre 19986), o tyle Emil Cioran i Fernando Pessoa traktowali ja jako podstawowy, niezbywalny element egzystencji.

O Cioranie powiada się - sam tak o sobie powiadal - że przez całe życie pisał tylko jedną książkę, będącą w istocie rozpisaną na akapity deklinacja słowa „rozpacz” (Czaja 2009: 246). Pisarstwo to cechuje się bowiem zmiennością stylu i niezmiennością wizji (Swoboda 2011: 373-374), jego ewolucja związana jest jedynie ze stopniowym „wyciszaniem”: od rozbuchanego liryzmu dzieł pisanych jeszcze po rumuńsku, do kostycznej formy fragmentu, o którym Cioran mówił, że wymierza się go tak, jak wymierza się policzek (1999: 66). „Napisałem dziesięć książek - pięć po rumuńsku, pięć po francusku. We wszystkich, od pierwszej do ostatniej, powracają te same obsesje, potem usuwają się, by zjawić się na powrót" (Cioran 2004: 657).

To ciągłe pisanie jednej książki, ciągłe myślenie jednej myśli sprawia, że twórczość Ciorana wymyka się jednoznacznemu ujęciu. Z pozoru łatwo przyszyć jej określone łatki (rozpacz, melancholia, nihilizm, pesymizm, sceptycyzm...), ale jej systematyczne ujęcie pozostaje niemożliwe ze względu na fragmentaryczny, wewnętrznie sprzeczny charakter. Wydaje się, że owa nieokreśloność, ta właściwość stylu Ciorana, który licytuje się tu z największymi mistrzami pisarstwa fragmentarycznego - od moralistów francuskich po Friedricha Nietzschego - wynika bezpośrednio z jego treści, rozpoznań, diagnoz i przekonań. Fragment stanowić ma bowiem adekwatny środek wyrazu, ukazujący nie tylko rozkład wielkich wartości kultury zachodniej (odnajdujemy tu pokrewieństwo ze wczesnym Sartre'em), ale

\footnotetext{
"Oczywiście, i tutaj „humanizm” rozumiany jest specyficznie: jako „optymistyczna” filozofia indywidualnego, niezdeterminowanego niczym nadawania sensu własnej egzystencji. Jeśli nie ma Boga, jeśli jesteśmy na świecie sami, nic nas nie poprzedza, żadne wartości nie istnieją, dopóki sami ich nie ustanowimy, jeśli - jak mówi słynne twierdzenie Sartre’a - „egzystencja poprzedza esencję" - to wszystko jest w moich rękach, sam jestem odpowiedzialny za swoje życie i za etyczny kontakt z Innym. Jednak w takim ujęciu znika cały radykalny krytycyzm wobec humanizmu jako takiego, jako filozofii antropocentrycznej, opresyjnej, totalitarnej, ujednolicającej, wykluczającej, przykrawającej wszystko do „normy”. Tak wygląda krytyka humanizmu jeszcze w Mdtościacb: „humanizm podejmuje, zbiera i stapia razem wszystkie ludzkie postawy. [...] Strawił tak antyintelektualizm, manicheizm, mistycyzm, pesymizm, anarchizm, egotyzm: teraz sa to tylko etapy, niepełne myśli, tylko w nim znajdujące swoje usprawiedliwienie. Mizantropia również zajmuje swoje miejsce w tym koncercie: [...] mizantrop jest człowiekiem: humanista musi więc być w jakiejś mierze mizantropem” (Sartre 1974: 169).
} 
także - rozbicie podmiotu, za którego główną przyczynę uznać należy właśnie nudę.

Cioran wyznawał, że jego „życie było zdominowane przez doświadczenie nudy. [...] Nie chodzi o nudę, którą można przezwyciężyć rozrywkami, rozmową czy przyjemnościami, ale o nudę, można by powiedzieć, fundamentalna, polegająca na tym, [...] że wszystko jest puste, nie ma treści ani sensu. [...] Cały wszechświat jest rażony nicością" (1999: 23). Pisarstwo Ciorana, począwszy od debiutanckiej książki Na szczytach rozpaczy, przez Sylogizmy goryczy, po O niedogodności narodżin, zdaje sprawę z niewygody istnienia, przejawiającej się w niemożności przezwyciężenia rozpaczy, melancholii, poczucia dezintegracji własnej osoby. Poglądy (czy też: obsesje) Ciorana zdają się bezpośrednim następstwem nudy, która - podobnie jak u Sartre’a - skutkuje nadmierną świadomością istnienia: „Właśnie poprzez nudę widzimy rzeczy, postrzegamy je i czujemy, że żyjemy. [...] W następstwie tego zaczynamy żyć w radykalnym oderwaniu od rzeczy. [...] Nuda jako coś stałego, przez całe życie, jest jednym z najokropniejszych doświadczeń człowieka" (Cioran 1999: 58). Jest to jednak nuda - co charakterystyczne dla Ciorana - działająca przewrotnie, ,nuda wybuchowa”, „nadludzka pustka”, „nieustanne załamywanie się wszystkiego”, „nieznośna gorączka”, „obsesyjne poczucie własnej nicości” (Cioran 2004: 11-19), niewiele zatem mająca wspólnego z potocznym doświadczeniem nudzenia się, dłużenia się czasu, bezczynności. Przeciwnie niż Sartre, Cioran pozostał „wierny” owemu doświadczeniu, nie tylko nie potrafiąc go przezwyciężyć, ale będąc wręcz przekonanym o niemożliwości jego przezwyciężenia. Nuda bowiem - owo uświadomienie sobie z całą jaskrawościa absurdu istnienia - jest czymś, co wydrąża, wyjaławia podmiot, ale co jednocześnie pozostaje najbardziej elementarnie, najbardziej fundamentalnie nim samym: „[Mówiąc o nudzie], mam na myśli istotową pustkę będącą uświadomieniem sobie samotności jednostki. To odczucie [...] naznacza nas tak głęboko oczywiście dlatego, że jest fundamentalnym wyrazem nas samych" (Cioran 1999: 101-102).

Fernando Pessoa z kolei określał nudę w sposób metaforyczny: „nic, które boli”. Także dla niego wiązała się ona z ciążącą świadomością istnienia, poczuciem odseparowania od świata oraz nieujarzmionym żalem z powodu przemijalności wszechrzeczy: „Nuda, która zawiera jedynie przeczucie jeszcze większej nudy, żal, odczuwany już teraz, że jutro będzie się żałowało tego, iż dzisiaj czuło się żal” (Pessoa 2007: 26). Rafał Koschany pisał, że Księa niepokoju, największe, nigdy nieukończone, opublikowane po śmierci, fragmentaryczne dzieło portugalskiego pisarza, „,kupia

\section{/ 46 STANRZECZY 2[11]/2016}


w sobie wszystkie niedomagania człowieka przełomu XIX i XX wieku", a gdyby pokusić się o stworzenie jej indeksu rzeczowego, otrzymalibyśmy takie hasła jak: abdykacja, absurd, bezwład, ból, dekadencja, klęska, nicość, niepokój, obojętność, rezygnacja, rozczarowanie, znużenie (2013: 32). Do listy tej z pewnością dodać należy nudę, o której znajdziemy w Księdže niepokoju sporo fragmentów.

Obraz nudy, jaki się z nich wyłania, nie pozostaje odległy od opisu tego fenomenu w Mdtościach Sartre’a i w twórczości Ciorana. Także dla Bernarda Soaresa - bohatera-narratora Ksiegi..., pomocnika księgowego mieszkającego i pracującego w Lizbonie, który większość życia przeżywa we własnej wyobraźni, uciekając przed bezsensem i miałkością codziennej egzystencji - stanowi ona rodzaj „zamaskowanego lęku metafizycznego, wielkiego, nieuświadomionego rozczarowania" (Pessoa 2007: 215). Także on zauważa demaskatorskie, pozbawiające iluzji, ujawniające krach wielkich wartości działanie nudy: „Nuda to brak mitologii. [...] Tak, to właśnie jest nuda: utracenie przez duszę zdolności łudzenia się" (Pessoa 2007: 216-217), przy czym - jak Goodstein, Valéry i wielu innych - podkreśla on jeszcze jeden jej aspekt: nieokreśloność, możliwość jedynie metaforycznego opisu tego stanu, który nie tylko odbywa się poza językiem (w tym sensie jest niemal czysto somatyczny), ale także demaskuje niedoskonałość języka - wszelkie jego językowe zapośredniczenie z natury rzeczy nie odda jego istoty, stanowić może najwyżej niedoskonała próbę uchwycenia jego paradoksalności Soares celuje w takich próbach, nazywając nudę „myśleniem bez myśli, ale z uciążliwością myśli, odczuwaniem bez odczuć, ale z niepokojem odczuć, zrezygnowaniem bez rezygnacji, ale z mdłościami [znów mdłości!] rezygnacji”, nakazującym doświadczającemu jej podmiotowi „cierpieć bez cierpienia, chcieć bez ochoty, myśleć bez sensu” (Pessoa 2007: 215-216). Zauważmy, że mamy tu do czynienia z czymś jeszcze: nuda pozbawia podmiot statusu agensa, skazuje go na bierność, wtrąca w stan, nad którym on nie panuje, wewnątrz którego się autoalienuje, ale który - jednocześnie - uświadamia mu jego własny podmiotowy byt: „Coś izoluje nas od nas samych, ale to, co wyznacza tę barierę, jest równie zastygłe jak my" (Pessoa 2007: 216). Zaryzykować można więc twierdzenie, że tym, co czyni nuda z podmiotem według Soaresa, jest wyjaławianie.

Ta krótka analiza dowodzi, mam nadzieję, słuszności tezy Goodstein inspirowanej Pasażami Waltera Benjamina, że „nuda jest chorobą podmiotów nowoczesnych" (2005: 2), która - jak z kolei pisał Gustave Flaubert - „przeżera ludzkie wnętrzności [znów fizjologia] i czyni z istoty myślą-

${ }^{7} \mathrm{Na}$ ten temat zob. także: Bałus 1996, szczególnie rozdział 3. 
cej chodzący cień, myślący fantom" (1973: 208-209, cyt. za: Goodstein 2005: 2). Można oczywiście czytać Pessoę i Ciorana (w mniejszym stopniu Sartre’a) przez pryzmat narzędzi geopoetyki i określić ich doświadczenie nudy jako wariant ponadczasowej, specyficznie „narodowej” melancholii czy nostalgii - w Portugalii nazywanej saudade (zob. Roszak 2013), a w Rumunii dor (zob. Stempowski 2005). Chciałbym jednak położyć nacisk na kontekst nowoczesności jako konkretnej epoki, której wszyscy trzej pisarze są nie tylko reprezentatywnymi, ale i wybitnymi przedstawicielami, dajacymi obraz wyostrzonej świadomości nieodwracalnych zmian dokonujących się w kulturze europejskiej w czasach modernizmu. Nie bez powodu Stefan Chwin dowodził, że doznanie Mdłości przez wiele lat pozostawało jedna z podstawowych metafor psychologiczno-filozoficznego doświadczenia nowoczesności (2010: 333), co koresponduje ze słowami samego Sartre’a dotyczącymi wprawdzie bezpośrednio surrealistów, ale pośrednio wielu modernistów, z nim samym (oraz z Cioranem i Pessoą) włącznie:

Wszyscy oni wyruszyli w poszukiwaniu absolutu, a ponieważ ze wszystkich stron osaczała ich relatywność, to absolut utożsamili z tym, co niemożliwe. Wszyscy wahali się między dwiema rolami: rolą zwiastuna nowego świata a rola niszczyciela świata starego (Sartre 1948: 228, cyt. za: Puszko 1988: 52).

\section{/// Nowoczesna triada: nuda - nihilizm - anomia}

Cytowana już Elizabeth Goodstein twierdzi, że nuda jest typowym stanem podmiotu doświadczającego kulturowej modernizacji i industrializacji, warunkującej poczucie zagubienia w świecie i niepewność co do własnej istoty, czyniącej z podmiotu - by posłużyć się tytułem słynnej powieści Roberta Musila - „człowieka bez właściwości”. Ów stan znamy bardzo dobrze także pod innymi nazwami: ,anomii” bądź „,nihilizmu” - charakterystycznego dla społeczeństw nowoczesnych poczucia bezsensu, braku powszechnie obowiązujących norm, załamania się tradycyjnych hierarchii wartości. Owa triada: anomia - nihilizm - nuda egzystencjalna, zdaje się ze sobą silnie spleciona. Przyjrzyjmy się dwóm cytatom:

To, co opowiadam, jest historią dwóch najbliższych stuleci. Opisuję, co będzie, co inaczej już być nie może: pojawienie się nihilizmu (Nietzsche 2009: 7). 
Przez ostatnie dwieście lat relatywizm epistemologiczny, głęboka rezerwa wobec idei postępu, waga przykładana do procesów nieświadomych lub motywowanych ideologicznie, stały się wszechobecne (Goodstein 2005: 103).

Nigdy dość podkreślania, że nihilizm - tak, jak rozumie go Nietzsche, i tak, jak implicytnie opisywany jest przez Goodstein - nie ma nic wspólnego z potocznym rozumieniem tego słowa, w którym traktuje się je jako światopogląd, przeciwieństwo moralizmu, trywialną destrukcję wartości czy wulgarny ateizm. Prawdziwy, głęboki nihilizm - od Nietzschego, przez Martina Heideggera, po Gianniego Vattima i innych współczesnych badaczy tego zagadnienia - jest zawsze rodzajem diagnozy ontologicznej: oto wartości, w jakie wszyscy wierzyliśmy, wyczerpały się, oto fundamenty, na jakich wsparty był nasz świat, okazały się kruche. Diagnoza taka nieuchronnie pociaga za sobą implikacje etyczne. Nihilista bowiem to - zgodnie $z$ definicją Nietzschego - ktoś, kto sądzi o świecie, który być powinien, że nie istnieje, a o świecie, który istnieje - że nie powinno go być (zob. Nietzsche 2009: 197).

Ważniejsze jednak w tej interpretacji okazuje się zakotwiczenie nihilizmu w epoce nowoczesnej. Nie jest on bowiem błędną drogą czy też ślepa uliczka, w jaką zabrnęła myśl zachodnia, ale - dokładnie odwrotnie: „przemyślaną do końca logiką naszych wielkich wartości i ideałów" (Nietzsche 2009: 13), swego rodzaju dolą, losem, przeznaczeniem kultury Zachodu, znajdującą kulminację właśnie w epoce nowoczesnej jako tej, która doprowadziła do skraju takie pojęcia jak Bóg, prawda, podmiot, ujawniając ich iluzoryczność (zob. też Vattimo 2006). Nie chodzi przy tym o dokonane przez Nietzschego rozgraniczenie nihilizmu biernego i aktywnego - oba one są bowiem reakcją na bardziej „obiektywny” proces utracenia przez wartości (z)wartości, z którym - tak czy owak, biernie bądź czynnie, destrukcyjnie bądź afirmatywnie - każdy modernista musiał się zmierzyć.

$\mathrm{Na}$ stan ten szczególnie wyczuleni byli interesujący mnie pisarze, zupełnie jakby nuda, melancholia czy rozpacz predestynowały ich do uświadomienia sobie $\mathrm{z}$ całą mocą anomii i nihilizmu przeżerających kulturę. Zarówno wszechstronna krytyka humanizmu, jaką odnajdziemy na kartach Mdtości Sartre'a, jak i fragmenty Ksiegi niepokoju, w których Pessoa/Soares pisze o nowoczesności jako czasie utraty wiary w Boga oraz walki wydanej staremu światu ${ }^{8}$, a także rozległy obraz „zarysu rozkładu” kultury zachod-

${ }^{8}$ Co ciekawe, bohater/narrator Ksiegi niepokoju oskarża o tę destrukcję poprzednie pokolenia: „Niszczycielska działalność poprzednich pokoleń sprawiła, że świat, na który przyszliśmy, nie 
niej, jaki dał w swoich książkach Cioran, noszą wyraźne piętno świadomości nihilistycznej.

W tej perspektywie warunkowany przez nudę rozpad podmiotu okazywałby się jedynie aspektem znacznie szerszego procesu kulminującego w modernizmie. Samą nudę zaś określić by można jako świecką wersję religijnej trwogi (zob. Toohey 2012: 28). Trwoga ta - znów - przybierałaby specyficznie nowoczesna postać o proweniencji Kierkegaardowsko-Heideggerowskiej. O ile duński filozof dokonywał dystynkcji pomiędzy lękiem a trwogą, twierdząc, że pierwszego doznajemy wobec zewnętrznych względem nas bytów, drugiej zaś - wobec samych siebie, stając w obliczu różnorodnych możliwości samorealizacji (zob. Gadacz 2009: 476) ${ }^{9}$, o tyle zdaniem autora Bycia i czasu trwoga stawia nas oko w oko z nicością i każe uświadomić sobie naszą obcość wobec świata i samotność własnej egzystencji (zob. Kossak 1976: 45-46). Związek tak pojętej trwogi z nudą egzystencjalną wydaje się niepodważalny.

W jaki jednak sposób nuda egzystencjalna powoduje dezintegrację podmiotu? Roquentin Sartre'a, Cioran i Soares Pessoi ${ }^{10}$ to podmioty rozbite, sfragmentaryzowane, rozproszone, nieposiadające stałej tożsamości. Jak pamiętamy, we wczesnym egzystencjalizmie Sartre’a stan ten związany jest z dualizmem bytu-w-sobie, który ,jest tym, czym jest - ponieważ nie ma w nim jakiejkolwiek zewnętrzności [...]. Jest masywny, nie ma w nim żadnej tajemnicy czy sekretu. Jest pełną pozytywnością. Jest całkowita syntezą z sobą samym" (Jędraszewski 1994: 16), i bytu-dla-siebie, czyli świadomości, która „jest pozycjonalna w tym sensie, że transcenduje ona siebie, aby dosięgnać przedmiotu i wyczerpuje siebie w samej tej pozycji” (Sartre 1957: 18, zob. także Sartre 2007: 115-122). Taka ontologia implikuje autoalienację człowieka, bytu-dla-siebie, który jest tym, czym nie jest, i nie jest tym, czym jest. Ciekawa w tym kontekście okazuje się etymologia

mógł nam dać bezpieczeństwa w dziedzinie religii, podpory w dziedzinie moralności ani spokoju w dziedzinie polityki. Zrodziliśmy się od razu w skrajnym lęku metafizycznym, skrajnym lęku moralnym i skrajnej niepewności politycznej" (Pessoa 2007: 148).

9 Związek Kierkegaarda z filozofią nudy, problematyką egzystencji, dekonstrukcja podmiotu to zresztą osobne zagadnienie, na którego analizę brak miejsca w niniejszym artykule. Najbliższą moim rozważaniom interpretację pisarstwa Kierkegaarda prezentuje John D. Caputo (1987, 2007). ${ }_{10}$ Warto zwrócić uwagę na problematyczność dystynkcji pomiędzy Sartre'em i Roquentinem oraz Pessoą i Soaresem. Jak dowodzi przywoływany wcześniej cytat (Sartre 1968: 201), francuski pisarz do pewnego stopnia utożsamiał się ze swym bohaterem. Jeszcze bardziej skomplikowana jest relacja Pessoi i Soaresa. Portugalski pisarz podpisywał swoje dzieła nazwiskami heteronimów-stwarzanych przez siebie postaci o całkowicie odmiennych biografiach, bibliografiach i charakterach. Pessoa stworzył aż 72 heteronimy, Soares zaś jest tu szczególnym przypadkiem: nazywany przez autora Ksiegi... pół-heteronimem, najbliższym jemu samemu, pojawiającym się w chwilach otępienia i niemożliwości głębszej refleksji, okazuje się właśnie... projekcją Pessoańskiej nudy? Na temat idei heteronimów zob. np. Charchalis 2011, Markowski 2009, Tabucchi 2002. 
nazwiska Roquentin, wywodzącego się od starofrancuskiego „un rocantin”, co oznaczało piosenkę złożoną z fragmentów innych piosenek (zob. Franczak 2002: 85-86). Roquentin (ale przecież także Soares i Cioran, a na dobrą sprawę - każdy podmiot nowoczesny) jest więc zlepkiem złożonym z własnych kompetencji kulturowych, całością sformułowaną z elementów nazbyt heterogenicznych, by nie okazały się one wewnętrznie sprzeczne.

Z podobną autoalienacją, choć pozbawioną filozoficznego sztafażu pojęciowego, mamy do czynienia u Ciorana i Pessoi. Kilka cytatów: jestem „człowiekiem poskładanym z kawałków”, „myślą rozsypaną w proch”, „umysłem nieciągłym”, „składam do kupy własne odłamki”, „mój umysł jest wyrwany z qawiasów przez przenikliwość" - powiada Cioran (2004: 84, 385, 45, 13, 212). „Myśląc, uczyniłem z siebie echo i otchłań”, „W najgłębszej intymności moich myśli nie byłem sobą”, „Jestem koczownikiem w świadomości siebie”, ,Jestem ruinami budynków, które nigdy nie były niczym więcej niż ruinami; nieukończoną budowlą, którą ktoś porzucił w połowie, bo miał dosyć zastanawiania się nad tym, co buduje" - wyznaje Pessoa/Soares (2007: 89, 42, 98, 62).

\section{/// Nuda, czyli podmiot w rozkładzie}

Wszystko to pozwala, moim zdaniem, potraktować zwłaszcza Ciorana i Pessoę jako przykłady nowoczesnego kryzysu podmiotowości. Podmiot nowoczesny staje bowiem twarza $\mathrm{w}$ twarz $\mathrm{z}$ własnym bezsensem (zob. Goodstein 2005: 46), a nuda - jak niejednokrotnie podkreślano - jest jego dolą i podstawowa przyczyną drążącego go poczucia absurdu. Jak zauważa Goodstein, „nowoczesna nuda, która przybiera postać uniwersalnej cechy kondycji ludzkiej, [...] podaje w głęboką wątpliwość znaczenie egzystencji i sensowność działania" (2005: 100). Można bowiem powiedzieć, że nuda, melancholia, rozpacz są radykalnie antykartezjańskie. Tym, co podważają, jest właśnie idea racjonalnego, samoświadomego, punktowego i wewnętrznie spójnego nowożytnego cogito. Podmiot melancholijny ${ }^{11}$ - jak wykazywał

\footnotetext{
${ }^{11}$ Relacja między melancholią a nudą zdaje się równie nieokreślona (nierozstrzygalna?) jak samo pojęcie nudy. Z jednej strony uprawnione wydaje się myślenie utożsamiające oba terminy: nuda okazywałaby się tu specyficznie nowoczesnym aspektem, przejawem czy wariantem „ponadczasowego” i „uniwersalnego” doświadczenia melancholii. Z drugiej wszakże strony istnieje niemożliwe do jednoznacznego określenia „coś” nudy, co zbliża ją również np. do nostalgii. Prawomocność takich, a nie innych ujęć gwarantuje, jak się zdaje, nierozstrzygalność samej nudy. Można by więc powiedzieć po wittgensteinowsku, że pojęcia „nudy”, „melancholii”, „nostalgii” cechuje - przy całej ich różnorodności - swego rodzaju „podobieństwo rodzinne”. Dobry przykład takiego upłynnienia granic pomiędzy nimi stanowi twórczość Ciorana, dająca się opisać zarówno w kategoriach nudy, jak i melancholii czy nostalgii, czego dowodzą artykuły zamieszczone
} 
swego czasu Marek Bieńczyk - jest „zdezintegrowany, nie daje się już pomyśleć jako całość”, podlega depersonalizacji, jest „konfuzją i wielością, pomieszaniem wszystkiego ze wszystkim", niedoistnieniem poddanym obsesji kruchości i przypadkowości istnienia, staje się „rozpadłymi cząstkami, fragmentami uwięzionymi w samotności, w obecności bezwładnej i niepewnej” (2012: 23-24, 25, 32, 48, 59, 84). „Melancholik - jak z kolei pisała Susan Sontag - nie tyle jest świadkiem ruiny, ile sam stanowi ruinę" (cyt. za: Roszak 2013: $153^{12}$ ).

Ta żmudna enumeracja - notabene będąca jedna z podstawowych strategii pisarstwa melancholijnego: Cioran wciąż nawracający do własnych obsesji, Pessoa rozpisujący swoja rozpacz na parataktyczne fragmenty - służy uargumentowaniu tytułowej tezy mojego artykułu. W tej perspektywie bowiem nuda okazywałaby się swoista „,dekonstrukcją” podmiotu nowoczesnego. Swoistą, bo pozbawiona ,metody”13 dekonstrukcji jako specjalistycznej strategii filozoficznej dokonującej rozbiórki podstawowych pojęć metafizycznych, ale działająca niejako w samych trzewiach egzystencji. Jako się rzekło, jej praca byłaby głęboko dwuznaczna - byłaby ruchem autoalienacji, ale jednocześnie samouświadomienia, ambiwalentnym ruchem ja-łowienia. A zatem nie czymś, co w taki lub inny sposób cechuje podmiot nowoczesny, ale raczej samą jego ,zasadą działania”. Ruchem „w tę i we w tę", ustanawiającym kryzys podmiotu nowoczesnego już w chwili jego narodzin.

Wprowadźmy jeszcze jeden kontekst. Na dwa lata przed Sartre'em, w pochodzącym z 1936 r. eseju O uciekaniu, Emmanuel Lévinas także użył terminu „mdłości”, określając je jako:

stan nudności, który [...] osacza nas zewsząd. Nie osacza nas jednak z zewnątrz. Nudności wzbierają w nas od wewnątrz; nasza własna istota dławi się od nas samych. Jest nam mdło „od środka”. [...] W mdłościach tkwi pewnego rodzaju odmowa przebywania w tym stanie, wysiłek, aby się z niego wydostać. Wysiłek ten jest jednak natychmiast uznany za beznadziejny [...]. Beznadziejność ta, fakt bycia przykutym do siebie leżą u podstaw lęku, jaki wywołują mdłości. W mdłościach, które są wszak niemożnością bycia

\footnotetext{
w ostatniej polskiej książce zbiorowej na temat rumuńsko-francuskiego autora (zob. Piechaczek 2014).

12 Autorka nie podaje - niestety - źródła cytatu.

13 „Metoda” z konieczności uzyskuje tu znaczenie metaforyczne. Wiadomo, że dekonstrukcja jest raczej „metodą bez metody”, że - jak zaznaczał Jacques Derrida - stanowi zawsze jednostkowa, niepowtarzalna, pozbawioną metodycznych uroszczeń relację z tekstem.
} 
tym, czym się jest, jednocześnie jest się do samego siebie przykutym, zamkniętym w ciasnym, duszącym kręgu (2007: 29-30).

Odnajdujemy w tym cytacie wszystko, o czym była mowa do tej pory. Mdłości nie są jakąś choroba podmiotu, ale jego niezbywalną kondycją. Sa pewną nadwyżką, która pojawia się w strukturze świadomości, „wewnętrznym Innym", niemożliwym do przyswojenia, wymykającym się próbom utożsamienia, wyobcowującym podmiot. Ale jednocześnie są czymś, co podmiot konstytuuje, z czego podmiot - dążący przecież do samoustanowienia - nie może się wywikłać, co wciąż skazuje na fiasko próby jego wewnętrznego scalenia.

Niemożliwość bycia tym, czym się jest, a jednocześnie przywiązanie do siebie samego. Dotykamy tu najbardziej dekonstrukcyjnego potencjału nudy. Jeśli jest ona „dopełnieniem samego bycia bytu”, to dopełnieniem w rodzaju Derridiańskiego „suplementu”, bez którego nie może się obejść dopełniana całość, w istocie ujawniająca wewnątrz siebie pustkę podlegającą uzupełnieniu/zastąpieniu (zob. Derrida 2011). Jeśli działa ona w dwie strony równocześnie: podmiot nowoczesny nie istnieje bez nudy, ale też nuda uniemożliwia jego pełne zaistnienie (pełną obecność), to owo paradoksalne działanie można by określić jako jeszcze jeden przejaw pracy différance, wyrażanej przez Jacques'a Derridę m.in. w figurze farmakonu - będącego zarówno trucizną, jak i lekarstwem, stanowiącego immanentną nierozstrzygalność elementu, który podważa binarne opozycje metafizyczne (1992), tak jak nowoczesna nuda podważa opozycję tożsamości i Inności.

Nuda działałaby więc tak, jak Derridiański „nierozstrzygalnik” - byłaby niemożliwym do jednoznacznego zdefiniowania, pozbawionym określonej właściwości elementem, który rozbija pragnienie samoustanowienia i samoupewnienia podmiotu nowoczesnego. Nie okazywałaby się przy tym choroba „,specyficznie” nowoczesna - w nowoczesności raczej miałby swoją kulminację proces uświadamiania podminowującego wszelkie narracje tożsamościowe działania nudy. Owo działanie, będące swoistą „pracą od wewnątrz", antycypowałoby ideę dekonstrukcji, operując przy tym nie tyle w porządku intelektualnym, ile stricte egzystencjalnym. Z rzadka tylko zauważano ów związek nudy i dekonstrukcji. Marek Bieńczyk pisał, że:

na długo przed Derridą melancholia opisała na swój niefilozoficzny sposób, że w jej świecie, który jest światem bez początku i bez końca, światem, w którym wszystko już było i wszystko zostało zapisane, i wszystko kręci się w kole powtórzenia [...], nie ma imienia 
własnego. Jest tylko teatralne mnożenie masek, przybrań, alter ego w miejscu i w miejsce utraty (2012: 37).

Nieśmiało też wskazywano, że poddająca rozbiórce iluzje, na których wspiera się kultura zachodnia, filozofia Ciorana jest „dekonstrukcją bez dekonstrukcjonisty” (Sloterdijk 2005: 96), że instynktownie usytuować można ją w pobliżu dekonstrukcjonizmu (Filek 1997: 73), że przekonanie Pessoi, iż „nie ma jednego Ja, nie ma jednej osobowości”, że Ja jest tylko maską, za którą nic się nie skrywa, odsyła do ponowoczesnej krytyki podmiotu (zob. Markowski 2009). W podobnym kontekście usytuowała Sartre’a Małgorzata Kowalska, nazywająca autora Mdtości ostatnim metafizykiem i upatrująca jego miejsca pomiędzy Heglem a Derridą. Próbując „dostrzec zarówno to, co w Sartrze już «postmodernistyczne», jak to, co w postmodernizmie, choćby wbrew niemu, Sartre'owskie", badaczka uznała, że francuskiego filozofa potraktować można jako jednego z prekursorów ponowoczesności, szczególnie ponowoczesnej dekonstrukcji, jeśli uznać, że jej „najogólniejszym zamierzeniem [...] będzie dokonanie takiego "przesunięcia» w obrębie metafizyki, które odsłoni w niej samej tę maskowaną dwuznaczność, które pokaże niemożność utrzymania konstytutywnych dla metafizyki opozycji, a tym bardziej uprzywilejowanego miejsca tożsamości” (1997: 180, 185).

Nuda ujawnia w takim ujęciu swój krytyczny potencjał - jest nie tylko rozpaczliwym doświadczeniem / doświadczeniem rozpaczy, ale również narzędziem rozbiórki dogmatów racjonalizmu (zob. Goodstein 2005: 24), które skłania do przemyślenia na nowo kondycji ludzkiej i antycypuje wiele ponowoczesnych rozpoznań. Przy czym - jeszcze raz podkreślmy - nie stanowi ona jakiejś podmiotowej ,strategii”, jakiegoś podmiotowego działania, ale raczej tkwi w samej strukturze podmiotu nowoczesnego, podważając go jako racjonalny konstrukt. Dokładnie tak jak Derridiańska différance: tkwi w podmiocie, jednocześnie będąc i nie będąc nim. Dokładnie tak jak „tekst”, który nie jest rozkładany czy podważany przez dekonstrukcyjnie nastawionego interpretatora, ale sam na sobie inicjuje akt dekonstrukcji (zob. Hillis Miller 1991). Nuda stanowi więc swego rodzaju „wyostrzoną świadomość" nowoczesności, posiadająca zarówno znaczenie negatywne (podkreślane przez modernistów), jak i pozytywne (wydobywane przez postmodernizm oraz dyskursy emancypacyjne). 
Bibliografia:

/// Anderson B. 2004. Time-stilled Space-slowed: How Boredom Matters, „Geoforum", nr 35(6), s. 739-754.

/// Bałus W. 1996. Mundus melancholicus. Melancholiczny swiat w zwierciadle sætuki, Universitas.

/// Bieńczyk M. 2012. Melancholia. O tych, co nigdy nie odnajda straty, Świat Książki.

/// Caputo J.D. 1987. Radical Hermeneutics. Repetition, Deconstruction, and the Hermeneutic Project, Indiana University Press.

/// Caputo J.D. 2007. How to Read Kierkegaard, Granta Books.

/// Charchalis W. 2011. Dlaczego heteronimia?, [w:] F. Pessoa, Poezje zebrane Alberta Caeiro. Heteronimia I, tłum. W. Charchalis, Czuły Barbarzyńca Press, s. $5-6$.

/// Chwin S. 2010. Samobójstwo jako doświadczenie wyobraźni, Wydawnictwo Tytul.

/// Cioran E. 1999. Rozmony z Cioranem, tłum. I. Kania, Wydawnictwo KR.

/// Cioran E. 2004. Zeszyty 1957-1972, tłum. I. Kania, Wydawnictwo KR.

/// Czaja D. 2009. Lekcje ciemności, Wydawnictwo Czarne.

/// Derrida J. 1992. Farmakon, tłum. K. Matuszewski, [w:] Pismo filozofii, Inter Esse, s. 39-61.

/// Derrida J. 2011. To niebezpieczne u₹upetnienie..., [w:] O gramatologii, tłum. B. Banasiak, Wydawnictwo Officyna, s. 191-217.

/// Filek J. 1997. Stów kilka o ostatnim zpotę̇nej gromadki Rumunów, „Kwartalnik Filozoficzny", nr 2, s. 65-79.

/// Flaubert G. 1973. Correspondance, Gallimard.

/// Franczak J. 2002. Rzecz o nierzeczywistości. „Mdtości” Jeana Paula Sartre'a i „Ferdydurke” Witolda Gombrowicza, Universitas.

/// Gadacz T. 2009. Historia filozofii XX wieku. Nurty, t. 2: Neokantyzm, filozofia egzystencja, filozofia dialogu, Wydawnictwo Znak. 
/// Goodstein E. 2005. Experience without Qualities. Boredom and Modernity, Stanford University Press.

/// Hillis Miller J. 1991. Theory Now and Then, Duke University Press.

/// Jędraszewski M. 1994. W poszukiwaniu nowego bumanizmu. J.-P. Sartre E. Lévinas, Wydawnictwo Naukowe Papieskiej Akademii Teologicznej.

/// Koschany R. 2013. Banalność dnia. O prozie życia w Księdze niepokoju, [w:] Powinowactwa Pessoi. Sžkice krytyczne, red. J. Roszak, A. Żychliński, Wydawnictwo Naukowe UAM, s. 19-34.

/// Kossak J. 1976. Egzystencjalizm w flozofii i literaturæe, Książka i Wiedza.

/// Kowalska M. 1997. W posqukiwaniu straconej syntezy. Jean-Paul Sartre i paradygmaty filozoficznego myślenia, Wydawnictwo Spacja.

/// Kuhn T. 1968. Struktura rewolucii naukonych, tłum. H. Ostromęcka, Państwowe Wydawnictwo Naukowe.

/// Lévinas E. 2007. O uciekaniu, tłum. A. Czarnacka, Wydawnictwo IFiS PAN.

/// Mach E. 2009. Analiza wrażeń i stosunek sfery firycznej do psychicznej, thum. M. Miłkowski, Wydawnictwo Naukowe PWN.

/// Markowski M.P. 1999. L'ennui - ułamek historii, [w:] Nuda w kulturze, red. P. Czapliński, P. Śliwiński, Rebis, s. 290-316.

/// Markowski M.P. 2007. Polska literatura nowoczesna. Leśmian, Schul, Witkacy, Universitas.

/// Markowski M.P. 2009. Pessoa - kaznodzৃieja wyržeczenia, [w:] Życie na miare literatury. Eseje, Wydawnictwo Homini.

/// Mattheus B. 2008. Cioran. Portret radykalnego sceptyka, tłum. R. Reszke, Wydawnictwo KR.

/// Nietzsche F. 2009. Wola mocy. Próba przemiany wszystkich wartości, tłum. K. Drzewiecki, S. Frycz, Wydawnictwo Vis-à-vis/Etiuda.

/// Nycz R. 1997. Jezyk modernizmu. Prolegomena bistorycznoliterackie, Wydawnictwo Fundacji na Rzecz Nauki Polskiej, „Leopoldinum”.

/// Piechaczek S., red. 2014. Cioran - w pułapce istnienia, Zakład Poligraficzny Sindruk. 
/// Pessoa F. 2007. Ksiega niepokoju Bernarda Soaresa, pomocnika ksiegowego w Ližbonie, tłum. M. Lipszyc, Świat Literacki.

/// Prokopski J.A. 2007. Egzystencja i tragizm. Dialektyka ludzkiej skończoności. Krytyka nowożytnej i wspótczesnej myśli egzystencjalistycznej, Wydawnictwo Marek Derewiecki.

/// Puszko H. 1988. Mdtości - powiesć z tezq czy antynomia kłamcy, „Studia Filozoficzne", nr 11, s. 41-53.

/// Roszak J. 2013. Przestrzenia tu staje sie czas. Hǚün, saudade (w strone Fernanda Pessoi), [w:] Powinowactwa Pessoi. Szkice krytyczne, red. J. Roszak, A. Żychliński, Wydawnictwo Naukowe UAM, s. 149-164.

/// Sartre J.-P. 1948. Qu'est-ce que la littérature?, Gallimard.

/// Sartre J.-P. 1957. L'Être et le Néant, Gallimard.

/// Sartre J.-P. 1968. Stowa, tłum. J. Rogoziński, Państwowy Instytut Wydawniczy.

/// Sartre J.-P. 1974. Mdtości, tłum. J. Trznadel, Państwowy Instytut Wydawniczy.

/// Sartre J.-P. 1998. Egzystencjalizm jest humani₹mem, tłum. J. Krajewski, Wydawnictwo Literackie Muza.

/// Sartre J.-P. 2007. Byt i nicość. Zarys ontologii fenomenologiçnej, tłum. J. Kiełbasa $\mathrm{i}$ in., Wydawnictwo Zielona Sowa.

/// Sendyka R. 2015. Od kultury ,ja” do kultury „siebie”. O zwrotnych formach w projektach to $\dot{s}$ samosiciowych, Universitas.

/// Sheppard R. 2004. Problematyka modernizmu europejskiego, tłum. P. Wawrzyszko, [w:] Odkrywanie modernizmu. Przeekłady i komentarze, red. R. Nycz, Universitas, s. 71-140.

/// Sloterdijk P. 2005. Beqinteresowny odwet: notatka o Cioranie, tłum. K. Tórz, „Twórczość”, nr 6, s. 94-97.

/// Spacks P.M. 1995. Boredom: The Literary History of a State of Mind, University of Chicago Press.

/// Stempowski J. 2005. Eseje dla Kassandry, Słowo/Obraz Terytoria.

/// Swoboda T. 2011. Cioran po polsku, „Literatura na Świecie”, nr 1/2, s. $370-391$. 
/// Tabucchi A. 2002. Kuferpełen ludzi, tłum. A. Wasilewska, „Literatura na Świecie", nr 375-377(10-12), s. 96-119.

/// Toohey P. 2012. Historia nudy, tłum. K. Ciarcińska, Bellona.

/// Valéry P. 1960. Oewures, t. 2, Gallimard.

/// Vattimo G. 2006. Koniec nowoczesności, tłum. M. Surma-Gawłowska, Universitas.

/// Wilson C. 1959. Outsider, tłum. M. Traczewska, Wydawnictwo Literackie.

/// Zenith R. 2013. O „Księze niepokoju”, ttum. M. Lipszyc, „Literatura na Świecie", nr 3/4, s. 140-166.

\section{/// Abstrakt}

Na przykładzie twórczości trzech autorów: Jeana-Paula Sartre’a, Emila Ciorana i Fernanda Pessoi, autor artykułu udowadnia, że nuda jest jednym z najważniejszych wyznaczników modernizmu, powielając cechę przypisywaną samej tej epoce, prądowi lub zespołowi nurtów, jaką jest nieokreśloność. W artykule przedstawiona zostaje swoista „fenomenologia nudy", którą można wyprowadzić z pisarstwa powyższych autorów, wskazująca na „pogranicznośc” nudy - jest ona bowiem doświadczeniem przebiegającym na styku fizjologii i woli, skutkującym odczuciem nadmiaru istnienia, bezsensu egzystencji, absurdu świata. Nuda działa na podmiot destrukcyjnie - rozbija jego tożsamość, podważa jego substancjalność, ujawnia tkwiącą w nim wewnętrzną inność. Jako zjawisko charakterystyczne dla modernizmu porównana zostaje $z$ anomią i nihilizmem, wespół z którymi stanowi specyficzna „, triadę nowoczesną” - zbiór niezbywalnych doświadczeń, z którymi każdy modernista musiał się zmierzyć. W ostatniej części artykułu udowodniona zostaje teza, że nuda stanowi specyficzną dekonstrukcję podmiotu: działającą w samych trzewiach egzystencji „podstawę" zarówno inicjującą budowanie tożsamości, jak i uniemożliwiająca skuteczne zakończenie tego procesu.

Słowa kluczowe:

nuda, modernizm, dekonstrukcja, Sartre, Cioran, Pessoa 


\section{/// Abstract}

Using the writings of Jean-Paul Sartre, Emil Cioran, and Ferdinand Pessoa as examples, the author proves that boredom is one of the most important signs of modernism. It duplicates a feature ascribed to modernist movements or groups of movements, and to the era itself - indeterminacy. The author presents a kind of "phenomenology of boredom" that can be derived from the works of these three writers and points out its "bordering" status: It is an experience that takes place at the meeting point of physiology and will, causing a feeling of the excess of existence, the senselessness of being, or the absurdity of the world. Boredom acts on the subject destructively, fragmenting its identity, undermining its substantiality, and bringing to light its internal otherness. As a phenomenon specific to modernism, it can be compared with anomy and nihilism, with which it produces a "modern triad" - a set of unavoidable modern experiences. The last part of the article proves that boredom is also a kind of deconstruction of the subject: a visceral "foundation" of existence that both initiates the construction of identity and prevents the successful completion of this process.

Keywords:

boredom, modernism, deconstruction, Sartre, Cioran, Pessoa 